\title{
RM solicitada por dolor lumbosacro ¿Será por el mordisco de una alimaña?
}

\section{MR Requested for Lumbosacral Pain. Is it due to a Vermin Bite?}

José Pedro Mora-Encinas ${ }^{1}$ Yonil Gregorio Piña-Alcántara ${ }^{1}$

${ }^{1}$ Hospital Don Benito-Villanueva, Villanueva de la Serena, Badajoz,
España

Rev Argent Radiol 2022;85(Suppl S1):S24.

Se trata de una paciente de 63 años que refería dolor lumbosacro crónico. Al revisar las imágenes de la resonancia magnética (RM) (-Fig. 1), encontramos la imagen de la cabeza (con sus ojos, hocico y orejas), de una alimaña u otro mamífero parecido ( - Fig. 2) en la región sacra. ¿Será ese animal la causa del dolor en nuestra paciente?

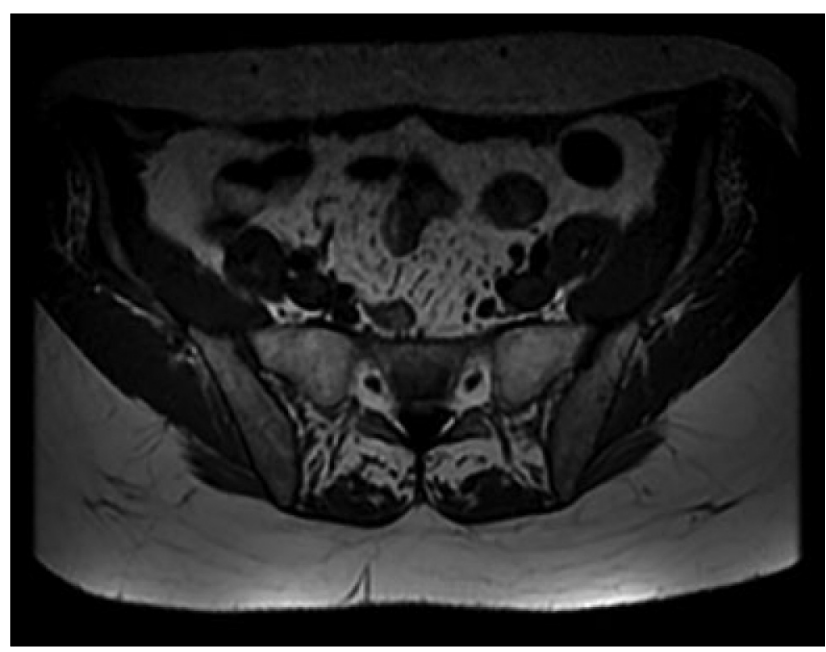

Fig. 1 Imagen axial potenciada en T1 de la región sacra.
Address for correspondence José Pedro Mora Encinas, MD, Hospital Don Benito-Villanueva, Carretera Don Benito Km 3, Villanueva de la Serena, Badajoz, España (e-mail: rastrapieses@gmail.com).

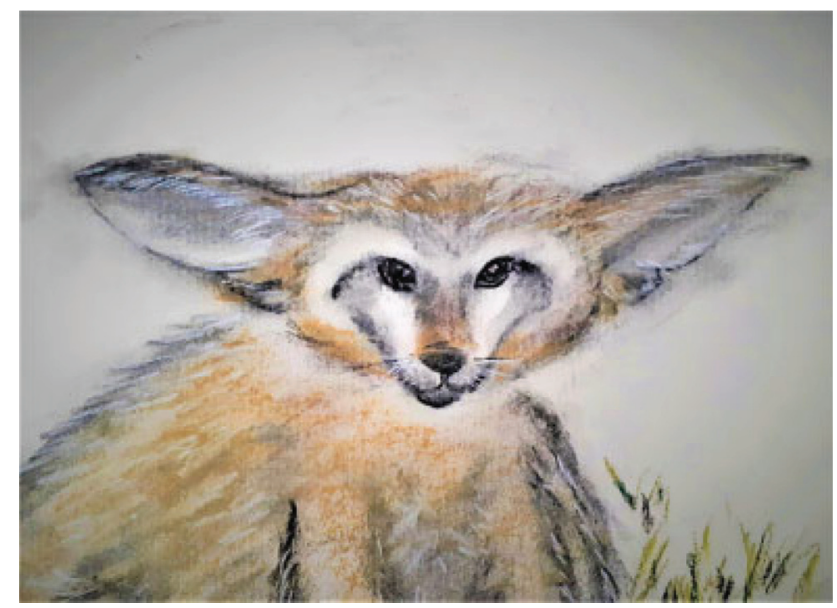

Fig. 2 Representación de un zorro orejudo (Otocyon megalotis). received

May 3, 2019

accepted

June 4, 2019

published online

September 25, 2019
DOI https://doi.org/

$10.1055 / \mathrm{s}-0039-1693671$.

ISSN 1852-9992. (c) 2019. Asociación Civil Sociedad Argentina de Radiología and Federacion Argentina de Asociaciones de Radiología, Diagnóstico por Imágenes y Terapia Radiante. All rights reserved.

This is an open access article published by Thieme under the terms of the Creative Commons Attribution-NonDerivative-NonCommercial-License, permitting copying and reproduction so long as the original work is given appropriate credit. Contents may not be used for commercial purposes, or adapted, remixed, transformed or built upon. (https://creativecommons.org/ licenses/by-nc-nd/4.0/)

Thieme Revinter Publicações Ltda., Rua do Matoso 170, Rio de Janeiro, RJ, CEP 20270-135, Brazil 